(C) 2020, The Authors. Published by Elsevier Inc. and Fass Inc. on behalf of the American Dairy Science Association ${ }^{\circledR}$. This is an open access article under the CC BY-NC-ND license (http://creativecommons.org/licenses/by-nc-nd/4.0/).

\title{
Short communication: The relationship between farm debt and dairy productivity and profitability in New Zealand
}

\author{
Wanglin Ma, ${ }^{1 *}$ ๑ Alan Renwick, ${ }^{1}$ and Xiaoshi Zhou ${ }^{2}$ (우 \\ ${ }^{1}$ Department of Global Value Chains and Trade, Faculty of Agribusiness and Commerce, Lincoln University, Christchurch, Lincoln 7647, \\ New Zealand \\ ${ }^{2}$ School of Economics and Management, Nanjing University of Science and Technology, Nanjing 210094, China
}

\begin{abstract}
For a variety of reasons, dairy sector indebtedness has increased in recent years. However, it is not clear whether increased debt boosts or damages the economic performance of dairy farms. This paper provides empirical evidence by exploring the effects of farm debt measured by debt-to-asset ratio on dairy productivity and profitability, using the New Zealand DairyBase data of 2,637 dairy farms for a 10-yr period 2005 to 2014. A fixed-effects panel data model is utilized for the empirical analysis. The findings show that farm debt is significantly and negatively associated with both dairy productivity and profitability. We find that dairy productivity is positively determined by production intensification, irrigation intensity, milking frequency, cattle breeds and stocking rate, whereas dairy profitability is positively affected by milk price, business type, milking frequency, and stocking rate. Further analyses reveal that the debt ratio significantly decreases both the technical efficiency of dairy farms and return on assets; a high debt ratio increased dairy productivity between 2005 and 2009, whereas it decreased dairy productivity between 2011 and 2014; the effects of the debt ratio on dairy profitability vary over time. The analysis for a 10-yr balanced panel data (250 farms) shows that debt ratio does not significantly affect both dairy productivity and profitability, which suggests that the presence of farm-specific attributes such as farm life cycle and managerial ability of dairy farmers may also affect the debt ratio and through this farm performance.
\end{abstract}

Key words: debt ratio, productivity, profitability, dairy farming, New Zealand

Received August 27, 2019.

Accepted May 2, 2020.

*Corresponding author: Wanglin.Ma@lincoln.ac.nz

\section{Short Communication}

In recent years, dairy sector indebtedness has increased in many dairy-producing countries such as New Zealand (Greig et al., 2019). Several factors may contribute to the growth of debt, including motivations to increase farm size and farm investments, changes in milk payment methods, access to irrigation, and movement from low-intensive to high-intensive farming systems that require greater use of purchased inputs such as supplementary feed (Mounsey, 2015; DairyNZ, 2017; Greig et al., 2019; Ma et al., 2020). In New Zealand, the level of debt has raised concerns over the resilience of the dairy sector, particularly the ability of highly indebted farms to withstand shocks such as sustained falls in commodity milk prices or higher costs. These concerns highlight the importance of understanding the relationship between debt levels and the performance of dairy farm businesses. If the higher debt is associated with poorer performance, this could exacerbate these risks. As discussed by Mugera and Nyambane (2015), conflicting theories exist as to whether the debt has a positive or negative effect on the economic performance of businesses. For example, based on the free cash theory, high debt levels and subsequent debt servicing burden motivate managers to become more efficient. On the other hand, agency theory suggests that borrowers with higher debt incur higher costs, which reduce the profitability and efficiency of their firms. Based on their review of credit evaluation theory, Mugera and Nyambane (2015) postulate that long-term debt may have a positive effect on business performance, whereas short-term debt does not.

Although several studies have analyzed the association between debt and firm performance (e.g., Campello 2006; Yazdanfar and Öhman 2015), less evidence is available about the effect of debt on farm performance (Mugera and Nyambane, 2015; Katchova and Dinterman, 2018). Zhengfei and Lansink (2006) highlight that generalization from corporate firms to farm businesses is unlikely to be appropriate given the differences in 
their structures (farm businesses are often familyowned, sole-traders or partnerships and land-based).

In this paper, we add to the literature by exploring the association between farm debt as measured by the debt-to-asset ratio and dairy productivity and profitability, using unbalanced panel data sourced from the New Zealand DairyBase database. The data include 7,636 observations from 2,637 farms that appear at least once in the database during a 10 -yr period from 2005 to 2014. New Zealand is an interesting case because of the recognized importance of the dairy sector for the national economy and also because it has a very high debt level on its dairy farms (Greig et al., 2019). The Reserve Bank of New Zealand estimated that New Zealand dairy farming debt was about NZ $\$ 40.75$ billion (equivalent to approximately US $\$ 26.17$ billion) in November 2019, which represented $64.50 \%$ of agricultural debts and $6.27 \%$ of the country's total debts. In addition, the difference in farm transition between New Zealand and other dairy countries such as the United States and China also makes the example of New Zealand interesting. In New Zealand, family farms are often transferred at the full market price from the older generation to the younger generation in a cycle of retirement and succession so as to ensure effective business management and maintain family relationships (McCrostie and Taylor, 1998; Nuthall and Old, 2017), but this increases the indebtedness of the successor and could adversely affect farm management.

Rather than simply measuring the amount of debt itself, the debt-to-asset ratio (hereafter, debt ratio) is a preferred indicator because it does not just focus on farm liabilities, but also takes into account the proportion of a farm's assets that can be financed with debts (Wolf et al., 2016). On-farm investment in New Zealand is typically debt-financed. An insolvent farm business would have a debt ratio higher than $100 \%$, whereas a smaller debt ratio would indicate greater farm equity and less risk of insolvency. Thus, debt ratio plays a significant role in practice because lenders may use the debt ratio to assess insolvency risks and will charge higher interest rates for farms with a higher debt ratio.

Following DairyBase (2006) and Wolf et al. (2016), the debt ratio (Debtratio) is calculated as follows:

$$
\text { Debtratio }=\frac{\text { short-term liabilities }+ \text { long-term liabilities }}{\text { total assets }} \times 100 \text {. }
$$

Conceptually, within this study we assume that the chosen indicator of dairy farm performance (either dairy productivity or dairy profitability) is a function of the debt ratio and a vector of farm-level characteristics.
In the context of panel data analysis, the regression specification can be expressed as follows:

$$
\begin{aligned}
& \log \left(\text { Performance }_{i t}\right)= \\
& \alpha+\beta \times \log \left(\text { Debtratio }_{i t}\right)+\gamma \times \sum_{j=1}^{8} \mathbf{X}_{i j t}+u_{i}+w_{t}+\varepsilon_{i t},
\end{aligned}
$$

where $\log \left(\right.$ Performance $\left._{i t}\right)$ refers to the log-transformed value of dairy productivity or dairy profitability for dairy farm $i$ at time $t$. The key explanatory variable $\log \left(\right.$ Debtratio $\left._{i t}\right)$ refers to the log-transformed value of the debt ratio. $\mathbf{X}_{i j t}$ is a vector of control variables including farm size, farming systems, milk price, business type, irrigation intensity, milking frequency, cattle breeds, and stocking rate. $\beta$ and $\gamma$ are parameters to be estimated, and $\alpha$ is a constant. $\mu_{i}$ refers to time-invariant individual characteristics for dairy farm $i$, whereas $w_{t}$ refers to year dummies that capture common shocks and unobserved regional characteristics that are timevarying but fixed at individual farm level at time $t$. $\varepsilon_{i t}$ is a random shock.

The Durbin-Wu-Hausman test was used to test the potential endogeneity issue associated with the debt ratio variable. The null hypothesis that the debt ratio is an exogenous variable cannot be rejected, suggesting that the fixed-effects model, random-effects model, or pooled-OLS model can all be used to estimate Equation [1]. We conducted both the Hausman test and $F$-test to select the most efficient estimation model.

To provide a better understanding of the effect of farm size on dairy farm economic performance, farm size is empirically measured at quartile levels. Following Mounsey (2015) and Ma et al. (2019a), we include variables representing production systems to capture the association between production intensification and dairy farm economic performance. The detailed definitions of these production systems are presented in Supplemental Table S1 (https://doi.org/10.3168/ jds.2019-17506). Because the dairy production systems are mainly categorized based on the timing, purpose, and amount of feed imported onto the farm and also because dairy farmers may use debt to purchase feed, we disaggregate the mean debt ratios by production systems (Supplemental Table S2, https://doi.org/10 $.3168 /$ jds.2019-17506). The results indicate that a higher production system (i.e., using more imported feed) is relatively associated with a higher debt ratio.

Table 1 presents the definitions and descriptive statistics of the variables used in the study. In the context of this study, dairy productivity refers to milk solids production per hectare whereas dairy profitability is 
Table 1. Definitions and descriptive statistics of the selected variables

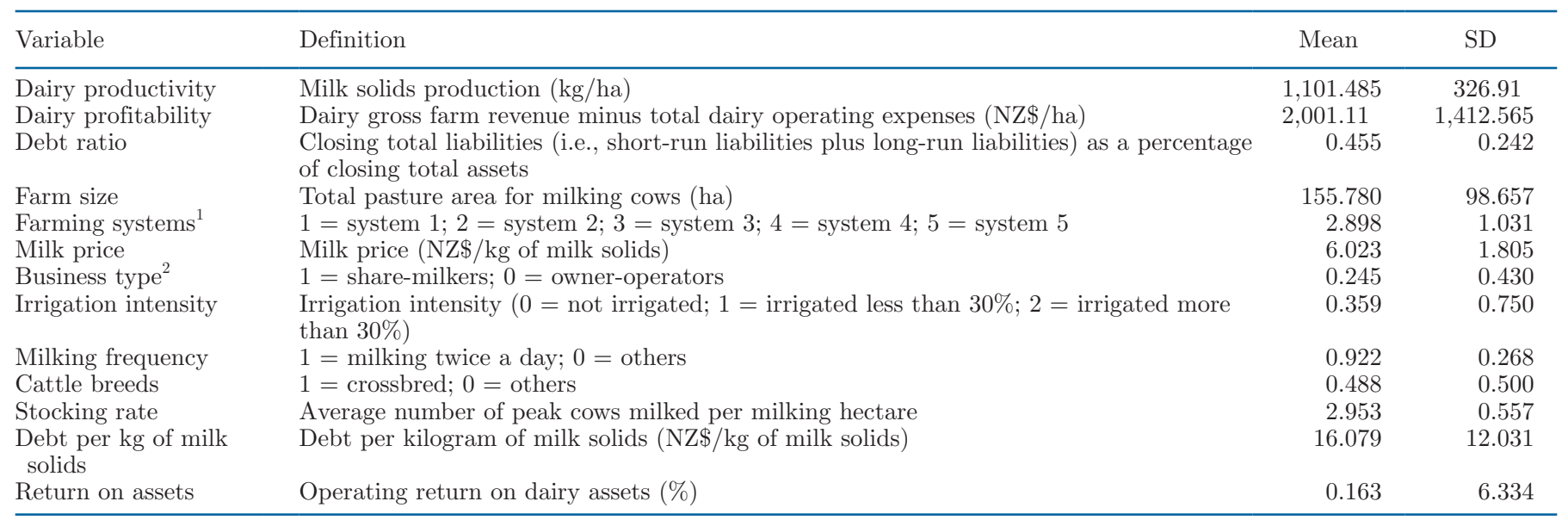

${ }^{1}$ The detailed definitions of the dairy farming systems are presented in Supplemental Table S1 (https://doi.org/10.3168/jds.2019-17506).

${ }^{2}$ Owner operators are farmers who either own and operate their own farms, or who employ a manager to operate the farm for a fixed wage, and share-milkers are farmers who operate a farm on behalf of the farm owner for an agreed share of the farm receipts (as opposed to a set wage; DairyNZ, 2017).

initially defined as the difference between dairy gross farm revenue and total dairy operating expenses, which is also measured at the per hectare level. It shows that the average dairy productivity and profitability as defined in this study are around $1,102 \mathrm{~kg} / \mathrm{ha}$ and 2,001 $\mathrm{NZ} \$ /$ ha, respectively. The mean of debt ratio is 0.46 , although as Supplemental Figure S1 (https://doi.org/ 10.3168/jds.2019-17506) illustrates, the debt ratio does fluctuate over the time period covered in this study (ranging between 0.36 and 0.52), reflecting among other factors the effect of unstable dairy commodity prices. The average farm size within the sample is 156 ha and the majority of dairy farms (i.e., 92\%) milked twice a day. On average, the stocking rate was around 3 cows per hectare of land.

Tables 2 and 3 present the empirical results, which are estimated using the (1) fixed-effects model, (2) random-effects model, and (3) pooled-OLS model. The significant Hausman tests suggest that the null hypothesis that the random-effects model is consistent and efficient can be rejected, whereas the significant $F$-tests imply that the null hypothesis that the fixedeffects are zero can be rejected. The findings together suggest that both the pooled-OLS and random-effects models would produce biased estimates and the results estimated from the fixed-effects model are preferred for interpretation.

We show that the coefficients of debt ratio variable are negative and statistically significant at the $1 \%$ level in both Tables 2 and 3, suggesting that farm debt is associated with lower dairy productivity and profitability. In part, to check the robustness of our results and also for the purpose of comparison, we also estimated the effect of debt per kilogram of milk solids on dairy farm economic performance and the results are presented in Supplemental Table S3 (https://doi.org/10.3168/ jds.2019-17506). These results confirm the negative relationship between farm debt and dairy farm performance.

Among other factors, farm size appears to be an important determinant of dairy productivity and profitability. Our results show that relative to the smallest dairy farms (those at farm size quartile 1), larger dairy farms (those at farm size quartiles 2-4) achieve significantly lower dairy productivity. The inverse relationship between farm size and output per unit of land has been found in other studies (Verschelde et al., 2013). Compared with pasture-based farming system 1 (the reference group), adoption of feed-based intensive farming systems 3 to 5 significantly increases dairy productivity, a finding that is largely consistent with previous studies (Mounsey, 2015; Ma et al., 2018). The coefficient of the business type variable in Table 2 is negative and statistically significant, whereas in Table 3 it is positive and statistically significant, suggesting that relative to owner-operators, share-milkers perform significantly better financially but not physically. The significant coefficient of the cattle breed variable in Table 2 suggests that, relative to farms with herds comprising other cattle breeds (e.g., Friesian, Jersey, and Ayrshire), farms with crossbred cows have greater dairy productivity, a finding that is consistent with previous studies (VanRaden and Sanders, 2003; Ma et al., 2019b). Tables 2 and 3 also show that both milking frequency (i.e., twice a day) and stocking rate contribute to higher dairy productivity and profitability. 
Table 2. Effect of debt ratio on dairy productivity ${ }^{1}$

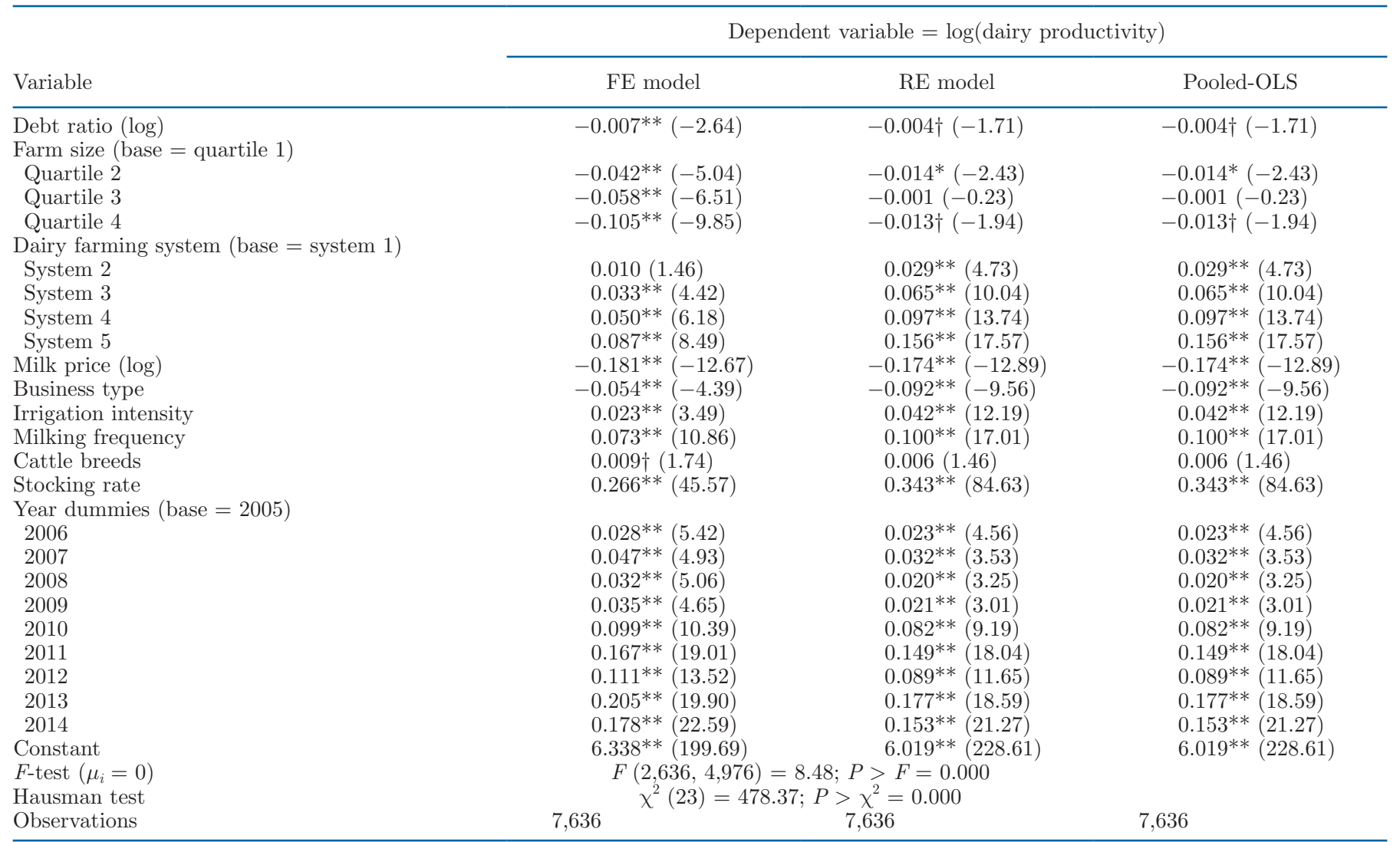

${ }^{1} t$-Statistics in parentheses. $\mathrm{FE}=$ fixed effects; $\mathrm{RE}=$ random effects; OLS = ordinary least squares regression model.

$\dagger P<0.1,{ }^{*} P<0.05,{ }^{* *} P<0.01$.

The descriptive analysis in Supplemental Table S2 (https://doi.org/10.3168/jds.2019-17506) shows that higher debt ratios are associated with higher input systems, but our results in Table 3 do not necessarily show that higher dairy profitability is correlated with higher input systems. This can be largely explained by the fact that dairy farmers in New Zealand receive the same milk price and farms operating at higher input systems also bear higher production costs (Ma et al., 2018).

While the relationship between yield and profit per hectare and the level of debt is of interest, these measures do have limitations in terms of understanding the association between debt and the performance of the business. To provide a more complete picture, we also estimate the effect of debt ratio on technical efficiency of dairy farms as well as the return on assets. Unlike variables that purely focus on output performance, technical efficiency enables the "optimal" relationship between inputs and farm output to be captured (Katchova and Dinterman, 2018). Return on assets can help reflect how profitable a farm's assets are in generating profits. In essence, it shows us how effective farm operators are in converting the money they invest into profits. Our results (Supplemental Tables S4 and S5, https://doi.org/10.3168/jds.2019-17506) show that debt ratio significantly decreases both the technical efficiency of dairy farms and return on assets. These results differ from those found by Mugera and Nyambane (2015) for cropping farms in Western Australia.

The changes in debt ratio (Supplemental Figure S1, https://doi.org/10.3168/jds.2019-17506) suggest that the debt ratio may have time-specific effects on dairy productivity and profitability. To explore this, we included multiplicative interaction terms for debt ratio and year dummies and re-estimated our model. The results (Supplemental Table S6, https://doi.org/ 10.3168/jds.2019-17506) reveal that a high debt ratio increased dairy productivity between 2005 and 2009, whereas it decreased dairy productivity between 2011 and 2014. The effects of the debt ratio on dairy profitability vary over time. The findings are not surprising because debt helps dairy farms relax capital constraints and can smooth income between financially good and financially difficult years (Greig et al., 2019).

In the samples we used, each farm was observed around 3 times on average. However, given the fact 
that poor-performing farms may be less likely to survive (and hence exit the survey), it may be the case that some form of bias is introduced as these farms may be less represented. Therefore, we conducted 2 additional estimations to consider the possible effects of farm exits. The first estimation dropped the farms with less than $5 \mathrm{yr}$ of observations, reducing the number of observations to 4,428 . The results (Supplemental Table S7, https://doi.org/10.3168/jds.2019-17506) show that debt ratio does not significantly affect dairy productivity but it significantly affects dairy profitability. The second estimation includes only those farms (250) for which observations are available for the whole $10 \mathrm{yr}$. The results (Supplemental Table S8, https://doi.org/ 10.3168/jds.2019-17506) show that debt ratio does not significantly affect both dairy productivity and profitability. The findings suggest that the presence of farm-specific attributes such as farm life cycle and managerial ability of dairy farmers may also affect the debt ratio and through this farm performance.

In this paper, we provide evidence that high dairy farm debt is associated with lower levels of farm per- formance in New Zealand when several other farm-level characteristics are controlled for. The existence of this relationship is of concern, as mentioned earlier, because of the high debt levels on a significant proportion of New Zealand dairy farms. It suggests that debt may indeed be a challenge to the resilience of the dairy sector. However, more detailed data than available for this study are required to enable a more definitive analysis of the relationship.

The credit evaluation theory postulates that there may be a difference between the relationship between long- and short-term debt and farm performance, and Mugera and Nyambane (2015) did find evidence of this in their study of Western Australia. However, our data do not distinguish between the 2 types of debt. In addition, debt and farm performance may vary through the life cycle of farm operators (Zhengfei and Lansink, 2006), but data are not available on the farm operator (for example, age and experience), which means that this could not be investigated in this study. Data that allow these sorts of analyses will help give a fuller picture of the relationship between debt and performance.

Table 3. Effect of debt ratio on dairy profitability ${ }^{1}$

\begin{tabular}{|c|c|c|c|}
\hline \multirow[b]{2}{*}{ Variable } & \multicolumn{3}{|c|}{ Dependent variable $=\log ($ dairy profitability $)$} \\
\hline & FE model & RE model & Pooled-OLS \\
\hline \multicolumn{4}{|c|}{ Farm size $($ base $=$ quartile 1$)$} \\
\hline Quartile 2 & $0.050(0.87)$ & $0.047(1.59)$ & $0.047(1.59)$ \\
\hline Quartile 3 & $0.090(1.50)$ & $0.108^{* *}(3.63)$ & $0.108^{* *}(3.63)$ \\
\hline Quartile 4 & $0.124 \dagger(1.71)$ & $0.154^{* *}(4.90)$ & $0.154^{* *}(4.90)$ \\
\hline System 3 & $-0.002(-0.03)$ & $-0.017(-0.47)$ & $-0.017(-0.47)$ \\
\hline System 4 & $-0.047(-0.85)$ & $-0.055(-1.39)$ & $-0.055(-1.39)$ \\
\hline System 5 & $-0.014(-0.20)$ & $-0.075(-1.51)$ & $-0.075(-1.51)$ \\
\hline Milk price (log) & $3.022 * *(31.24)$ & $2.676^{* *}(32.76)$ & $2.676^{* *}(32.76)$ \\
\hline Business type & $0.960 * *(11.46)$ & $0.720^{* *}(13.03)$ & $0.720 * *(13.03)$ \\
\hline Irrigation intensity & $0.032(0.70)$ & $-0.014(-0.86)$ & $-0.014(-0.86)$ \\
\hline Milking frequency & $0.141 * *(3.10)$ & $0.196 * *(5.94)$ & $0.196 * *(5.94)$ \\
\hline 2008 & $-0.977^{* *}(-22.55)$ & $-0.893^{* *}(-23.28)$ & $-0.893^{* *}(-23.28)$ \\
\hline 2009 & $-0.610 * *(-11.96)$ & $-0.484 * *(-11.08)$ & $-0.484^{* *}(-11.08)$ \\
\hline 2010 & $-0.644 * *(-9.99)$ & $-0.452^{* *}(-8.33)$ & $-0.452^{* *}(-8.33)$ \\
\hline 2011 & $-0.557 * *(-9.32)$ & $-0.380 * *(-7.59)$ & $-0.380^{* *}(-7.59)$ \\
\hline 2012 & $-0.826^{* *}(-14.75)$ & $-0.668^{* *}(-14.40)$ & $-0.668^{* *}(-14.40)$ \\
\hline 2013 & $-0.681 * *(-9.73)$ & $-0.470 * *(-8.19)$ & $-0.470 * *(-8.19)$ \\
\hline 2014 & $-0.737^{* *}(-13.78)$ & $-0.608^{* *}(-14.06)$ & $-0.608^{* *}(-14.06)$ \\
\hline Constant & $1.229 * *(5.71)$ & $1.111^{* *}(7.32)$ & $1.111^{* *}(7.32)$ \\
\hline$F$-test $\left(\mu_{i}=0\right)$ & \multicolumn{3}{|c|}{$F(2,636,4,976)=2.94 ; P>F=0.0000$} \\
\hline Hausman test & \multicolumn{3}{|c|}{$\chi^{2}(23)=132.77 ; P>\chi^{2}=0.000$} \\
\hline Observations & 7,636 & 636 & 7,636 \\
\hline
\end{tabular}

${ }^{1} t$-Statistics in parentheses. $\mathrm{FE}=$ fixed effects; $\mathrm{RE}=$ random effects; OLS $=$ ordinary least squares regression model. $\dagger P<0.1,{ }^{*} P<0.05,{ }^{* *} P<0.01$. 


\section{ACKNOWLEDGMENTS}

This research is one of a series of analyses in the Marginal Imperative Project funded by New Zealand dairy farmers through DairyNZ and the Ministry for Primary Industries in the Transforming the Dairy Value Chain Primary Growth Partnership Programme. The authors declare there are no conflicts of interest.

\section{REFERENCES}

Campello, M. 2006. Debt financing: Does it boost or hurt firm performance in product markets? J. Financ. Econ. 82:135-172. https:// doi.org/10.1016/j.jfineco.2005.04.001.

DairyBase. 2006. DairyBase ${ }^{\circledR}$ Report Description Handbook. DairyNZ, Hamilton, New Zealand.

DairyNZ. 2017. DairyNZ Economic Survey 2015-16. DairyNZ, Hamilton, New Zealand.

Greig, B., P. Nuthall, and K. Old. 2019. Resilience and finances on Aotearoa New Zealand farms: Evidence from a random survey on the sources and uses of debt. N. Z. Geog. 75:21-33. https://doi .org/10.1111/nzg.12207.

Katchova, A. L., and R. Dinterman. 2018. Evaluating financial stress and performance of beginning farmers during the agricultural downturn. Agric. Financ. Rev. 78:457-469. https://doi.org/10 .1108/AFR-08-2017-0074.

Ma, W., K. Bicknell, and A. Renwick. 2019a. Feed use intensification and technical efficiency of dairy farms in New Zealand. Aust. J. Agric. Resour. Econ. 63:20-38. https://doi.org/10.1111/1467-8489 .12283 .

Ma, W., K. Bicknell, and A. Renwick. 2020. Production intensification and animal health expenditure on dairy farms in New Zealand. J. Dairy Sci. 103:1598-1607. https://doi.org/10.3168/jds.2018-16039.

Ma, W., A. Renwick, and K. Bicknell. 2018. Higher intensity, higher profit? Empirical evidence from dairy farming in New Zealand. J. Agric. Econ. 69:739-755. https://doi.org/10.1111/1477-9552 .12261.

Ma, W., A. Renwick, and B. Greig. 2019b. Modelling the heterogeneous effects of stocking rate on dairy production: An application of unconditional quantile regression with fixed effects. Appl. Econ 51:4769-4780. https://doi.org/10.1080/00036846.2019.1602710.

McCrostie, H., and N. Taylor. 1998. Issues of New Zealand Farm Succession: A Study of the Intergenerational Transfer of the Farm Business Summary of findings and policy implications. MAF Policy Technical Paper 97/4a, Wellington, New Zealand.

Mounsey, Z. 2015. Analysis of Production Systems in the New Zealand Dairy Industry. DairyNZ Report, Hamilton, New Zealand.

Mugera, A. W., and G. G. Nyambane. 2015. Impact of debt structure on production efficiency and financial performance of Broadacre farms in Western Australia. Aust. J. Agric. Resour. Econ. 59:208224. https://doi.org/10.1111/1467-8489.12075.

Nuthall, P. L., and K. M. Old. 2017. Farm owners' reluctance to embrace family succession and the implications for extension: The case of family farms in New Zealand. J. Agric. Educ. Ext. 23:3960. https://doi.org/10.1080/1389224X.2016.1200992.

VanRaden, P. M., and A. H. Sanders. 2003. Economic merit of crossbred and purebred US dairy cattle. J. Dairy Sci. 86:1036-1044. https://doi.org/10.3168/jds.S0022-0302(03)73687-X.

Verschelde, M., M. D'Haese, G. Rayp, and E. Vandamme. 2013. Challenging small-scale farming: A non-parametric analysis of the (inverse) relationship between farm productivity and farm size in Burundi. J. Agric. Econ. 64:319-342. https://doi.org/10.1111/j .1477-9552.2012.00373.x.

Wolf, C., M. W. Stephenson, W. A. Knoblauch, and A. M. Novakovic. 2016. Dairy farm financial performance: Firm, year, and size effects. Agric. Financ. Rev. 76:532-543. https://doi.org/10.1108/ AFR-02-2016-0009.

Yazdanfar, D., and P. Öhman. 2015. Debt financing and firm performance: An empirical study based on Swedish data. J. Risk Finance 16:102-118. https://doi.org/10.1108/JRF-06-2014-0085.

Zhengfei, G., and A. O. Lansink. 2006. The source of productivity growth in Dutch agriculture: A perspective from finance. Am J. Agric. Econ. 88:644-656. https://doi.org/10.1111/j.1467-8276 .2006.00885.x

\section{ORCIDS}

Wanglin Ma (으 https://orcid.org/0000-0001-7847-8459

Xiaoshi Zhou ๑ https://orcid.org/0000-0003-1051-6097 